\title{
PARENTERAL NUTRITION IN A JOINT SERVICES CONTEXT
}

\author{
MAJOR M. J. PAYNE, M.B., B.S., F.R.C.S.(Ed.), R.A.M.C. \\ Royal Army Medical College, Millbank \\ MAJOR R. H. JAGO, M.A., M.B., B.Chir., F.F.A.R.C.S., R.A.M.C. \\ Cambridge Military Hospital, Aldershot
}

SUMMARY: A review of current thinking on parenteral nutrition is given. The pathophysiology, indications and practical applications are discussed. The preparations available are outlined and suitable regimes are illustrated using those solutions available through the Joint Services Catalogue.

\section{Introduction}

"To allow starvation and severe wasting with its attendant sequelae is tantamount to clinical incompetence." Lee H.A. (1974a).

Knowledge of the metabolic demands and consequences of injury is growing rapidly. There now exists a large number of preparations to meet these demands in patients who cannot feed orally or via a nasogastric tube. Numerous papers describing regimes of parenteral nutrition to meet varied clinical situations have been published.

The Service clinician, however, is not always able to take full advantage of the advice offered in these papers. He has a limited, but adequate, selection of the preparations described at his disposal. Furthermore, parenteral nutrition is the subject of continuing research and change.

The aim of this paper is to offer assistance in planning parenteral nutrition. The advice is based on accepted concepts. The rationale and indications for the procedure are discussed briefly and methods described utilising those preparations available through the Joint Services Catalogue.

\section{Pathophysiology}

Physiological insult, whether illness or injury, results in a metabolic response, the intensity of which is proportional to the severity of the insult. This response is initiated by central and peripheral stimuli. It is mediated by endocrine changes which alter the normal balance between catabolic and anabolic activities. The most important endocrine changes may be summarised as:

a. A rise in adrenocorticotrophin hormone (ACTH) secretion, leading to a rise in cortisol and aldosterone levels. $b$. Increased adrenaline and noradrenaline secretion. c. Increased glucagon secretion. d. Increased antidiuretic hormone (ADH) secretion.

The main inter-relationships between the major intermediate metabolites were summarised by Allison (1974) and are represented diagramatically in Figure 1.

From this it can be seen that adenaline, cortisol and glucagon increase catabolic activity, with resultant hyperglycaemia, gluconeogenesis, and increased nitrogen excretion. Aldosterone and ADH activity results in sodium and water retention and increased potassium loss. When nutritional intake is inadequate and 


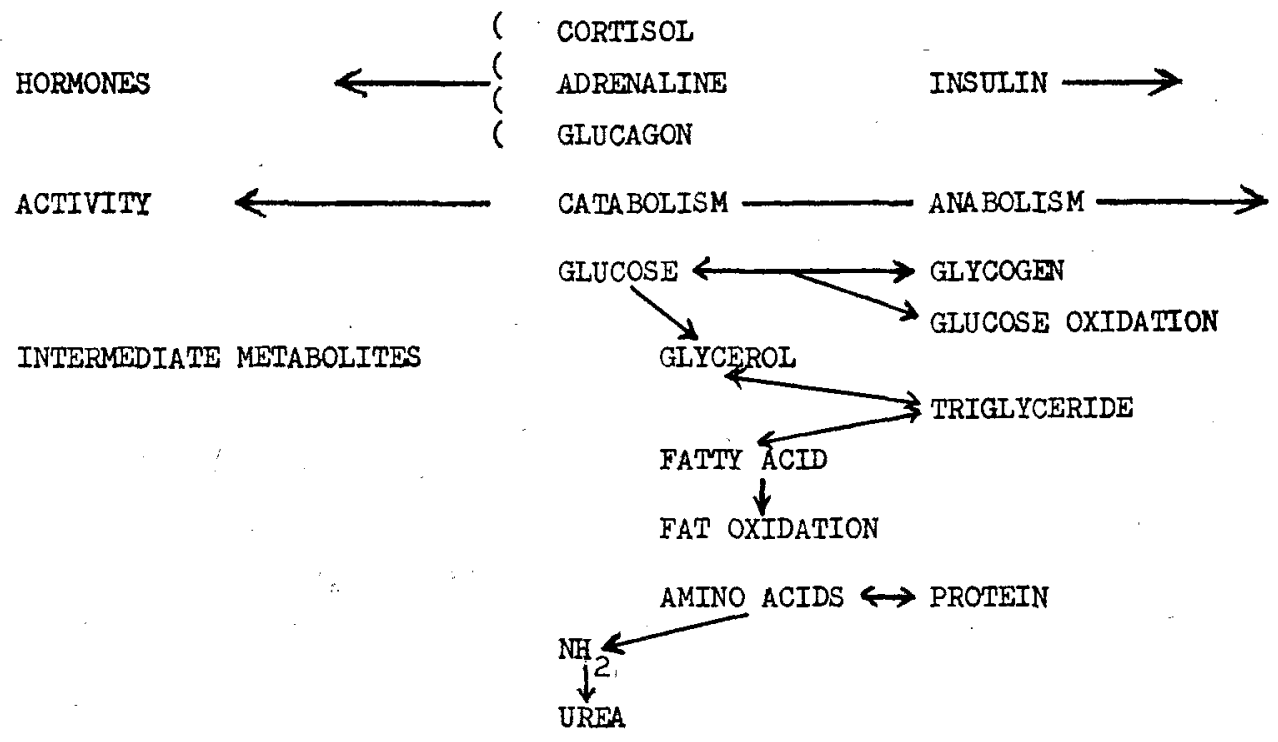

Fig 1. The inter-relationships of major intermediate metabolites, and the effect of hormones (Allison 1974)

carbohydrate reserves exhausted, an unabated catabolic response will act on depot stores of fat and lean body tissue. Weight loss, muscle wasting, failure of wound healing and decreased resistence to infection result.

Clinically several phases are well recognised, though less readily defined (Fig. 2). In the acute phase the patient is obviously ill, with neither the ability

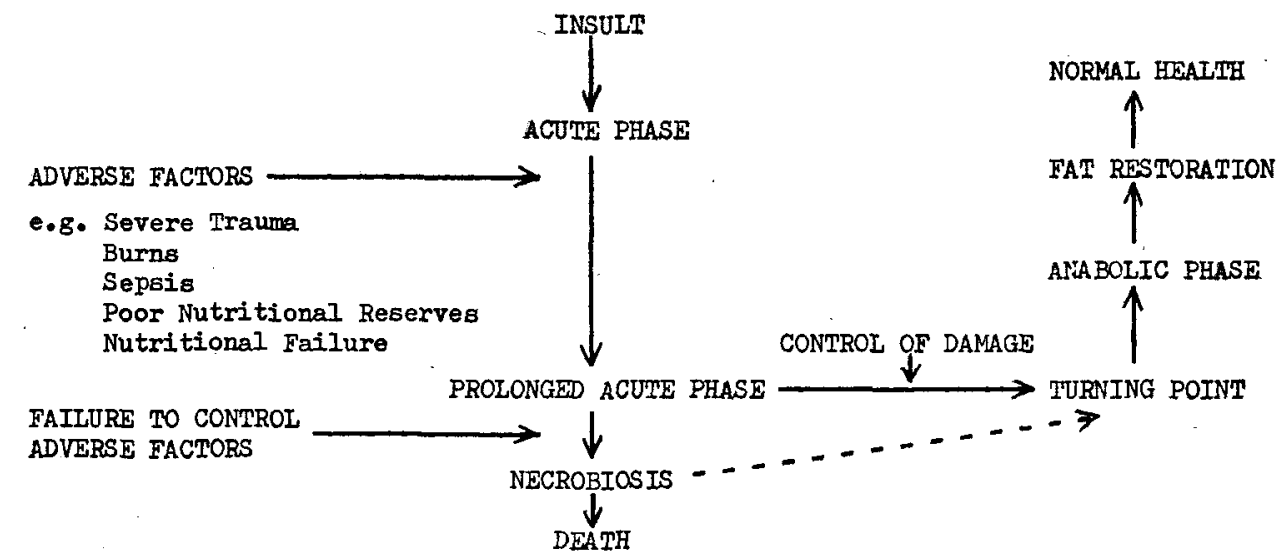

Fig. 2. Clinical states resulting from metabolic response to injury

nor inclination to feed. Sodium and water balance are positive, potassium and nitrogen negative. With limited insult, adequate reserves and early return of normal gastro-intestinal function the patient makes an uncomplicated recovery. 
A more severe insult or the added complications of sepsis, or nutritional failure will result in prolongation of the acute phase. The patient remains obviously ill for several days and signs of wasting appear. Control of adverse factors allows a turning point to be recognised when the patient begins to look and feel better and appetite returns. A sodium diuresis occurs, the negative nitrogen balance diminishes, and potassium balance becomes positive. Later in the anabolic phase nitrogen balance becomes positive and finally the fat depots are restored.

Failure to control adverse factors results in the state of necrobiosis characterised by gross wasting, cachexia, failure of wound healing and sepsis. Recovery from this stage does not occur without intensive therapy.

Quantitative estimates of protein losses during the catabolic response vary, but following a relatively non-traumatic operation such as vagotomy and pyloroplasty, nitrogen losses of the order of $10 \mathrm{~g}$ per day can be expected, and may persist for six to ten days (Lee 1974b). Since one gram of nitrogen excreted represents $6.25 \mathrm{~g}$ of protein catabolism, which in turn represents the loss of some $30 \mathrm{~g}$ of muscle tissue; these figures are equivalent to a daily loss of $300 \mathrm{~g}$ of muscle.

In severe burns, major trauma and sepsis, daily nitrogen losses may be of the order of 20 to $25 \mathrm{~g}$, which represents protein catabolism of 125 to $155 \mathrm{~g}$, or 600 to $750 \mathrm{~g}$ of muscle.This may persist for weeks rather than days.

This excessive breakdown of protein cannot be accounted for solely in terms of calorific requirement. In the most catabolic patients only 22 per cent of calorie consumption is supplied from protein sources (Kinney et al 1970). Control of gluconeogenesis is impaired and protein breakdown appears to be related to carbohydrate breakdown rather than calorie requirement, hence the necessity to provide an adequate supply of carbohydrate with protein replacement.

The main source of calories ( 70 to 90 per cent) in the unchecked catabolic response appears to be the fat deposits. It consequently follows that lean muscle loss will only represent a portion of total body weight loss. It is generally agreed that the loss of more than 30 per cent of body weight in an acute metabolic illness is rarely compatible with survival (Ileys 1948).

However catabolism can be contained by the adequate provision of calories and nitrogen. This has been well demonstrated by Moore (1959) whose results are summarised in Table I.

\section{Indications}

The majority of patients undergoing surgery or suffering the effects of trauma are able to withstand two or three days of relative starvation (fluids and electrolytes excepted) with no serious sequelae. Nutritional reserves and the normal rapid restoration of gastro-intestinal function are adequate to protect against adverse effects in the short term. Parenteral nutrition is however indicated in three situations:

a. Poor pre-operative nutritional states. b. Prolonged gastro-intestinal failure. c. Gross hypercatabolic states. 
Table I

Effect of trauma, Starvation and constant nitrogen and calorie supply on protein loss (data from Moore 1959)

\begin{tabular}{|l|c|c|c|}
\hline Minor trauma and starvation & $\begin{array}{c}\text { Cumulative-ve } \\
\mathrm{N}_{2} \text { balance }(\mathrm{g})\end{array}$ & $\begin{array}{c}\text { Duration } \\
\text { (days) }\end{array}$ & $\begin{array}{c}\text { Cumulative protein } \\
\text { loss (g) }\end{array}$ \\
\hline $\begin{array}{l}\text { Minor trauma and constant } \\
\mathrm{N}_{2} / \text { cal supply }\end{array}$ & 24 & 3 & 150 \\
\hline Major trauma and starvation & 107 & 2 & 18.8 \\
\hline $\begin{array}{c}\text { Major trauma and constant } \\
\mathrm{N}_{2} / \text { cal supply }\end{array}$ & 31 & 11 & 669 \\
\hline
\end{tabular}

Poor pre-operative nutritional states.

Patients in this group are uncommon in military hospitals. However this fact should alert us to the possibility that the patient coming to surgery may not be in the optimum nutritional state, especially at the extremes of age.

The importance of adequate fluid and electrolyte replacement is basic knowledge. Although less dramatic in presentation, and with a wider time scale in terms of loss and replacement, nutritional deficiencies should be similarly noted, assessed and, if necessary, corrected. Just as the infant with pyloric stenosis is rehydrated, and the multiple trauma victim transfused with blood before being subjected to surgery, so should the patient in poor nutritional state be improved. This is especially important when delay for a few days would greatly improve results without reducing long term prognosis.

Patients who have suffered a recent weight loss in excess of five kilograms appear to have impaired wound healing and immunological defence mechanisms. There is evidence that pre-operative feeding can reduce these abnormalities (Law, Dudrick and Abdou 1973) with consequent improvement in post-operative morbidity (Heatley and Hughes 1974).

\section{Prolonged gastro-intestinal failure}

This group may be further classified under three sub-headings:

a. Intake failure - e.g. coma, major head/neck surgery. b. Motility failuree.g. paralytic ileus, chronic obstruction. c. Absorption failure-e.g. fistulae, inflammatory bowel disease.

In the first group the possibility of tube feeding or gastrostomy should be considered, providing gastro-intestinal function is normal. Tube feeds are, however, often associated with complications of diarrhoea, reflux oesophagitis and aspiration. Hadfield (1975) suggests parenteral nutrition in the acute phase, followed later by a feeding gastrostomy.

More common is the situation of prolonged ileus following a major abdominal crisis, and the clinical problem is when rather than how to commence feeding. Too many of us "wait and see" for too long, with dire results in negative nitrogen balance. It is much easier to maintain nutrition than to replace lean body mass. 
It is therefore suggested that 72 hours after operation the clinical situation be reviewed. If the patient is not obviously progressing well the decision regarding parenteral nutrition must be made then, and not delayed. The therapeutic decision should not be to use parenteral nutrition, but rather the reverse-the decision not to feed should be the positive action which is to be justified (Peaston 1968).

\section{Hypercatabolic states}

These patients have normal gastro-intestinal function, but have a greatly increased nutritional demand that cannot be met solely by oral nutrition. This is especially so when the patient is weak and lethargic, as is often the case in severe burns and widespread sepsis.

\section{Route}

\section{Practical applications}

A caval catheter is the ideal, sometimes only, route of administration of fluids for parenteral nutrition. It is also the most dangerous. A prospective study of 3,241 cases, and a review of 11,000 cases of caval catheterisation for a variety of indications has been published by Burri and Henkemeyer (1972). Infection and thrombosis were the commonest complications. Caval catheterisation demands a high standard of care and asepsis, not only in introduction, but in continued maintenance. Such requirements, however, should never be allowed to constitute a contra-indication to parenteral nutrition.

By the selection of less hyperosmolar solutions, or the infusion of hyperosmolar ones through a Y-connector along with more isotonic solutions, peripheral veins may be utilised in many cases. Clinicians must be prepared to change the infusion site every 48 to 72 hours, which implies ready access to several upper limb veins. Veins in the lower limbs should not be used.

In respect of the route of administration patients fall into two categories:

Category I-Short term (of the order of one week). Basically supportive. Uncomplicated.

Category II —Long term, or hypercatabolic, or complicated by renal/cardiac/ hepatic problems.

Category I patients can usually be managed by peripheral lines. By definition they are short term, and provided no gross metabolic disorder pre-existed and therapy can be followed by normal diet, they can be managed on a simple regime since short term deprivation of elements such as magnesium and iron will produce no serious sequelae. Category II patients require caval catheterisation, more complex regimes, and trace element supplements.

\section{Requirements}

The requirements of each patient need to be individually assessed. Some guide to basal requirements, with no allowance for hypercatabolism or abnormal losses, are given by Wretlind's (1974) figures (Table II). The major components of any regime are water, electrolytes, protein and calories. The exact quantity of each needs to be assessed daily. 
Table II

Estimates of basal requirements of some dietary components (after Wretlind 1974)

\begin{tabular}{|l|l|l|}
\hline & per kg/body weight & for $70 \mathrm{~kg} \mathrm{man}$ \\
\hline Water & $30 \mathrm{ml}$ & $2100 \mathrm{ml}$ \\
\hline Energy & $30 \mathrm{~K} \mathrm{cal}$ & $2100 \mathrm{~K} \mathrm{cal}$ \\
\hline Sodium & $1-1.4 \mathrm{mmol}$ & $70-98 \mathrm{mmol}$ \\
\hline Potassium & $0.7-0.9 \mathrm{mmol}$ & $49-63 \mathrm{mmol}$ \\
\hline Chloride & $1.3-1.9 \mathrm{mmol}$ & $91-133 \mathrm{mmol}$ \\
\hline Amino acid nitrogen & $90 \mathrm{mg}$ & $6.3 \mathrm{~g}$ \\
\hline Calcium & $0.11 \mathrm{mmol}$ & $7.7 \mathrm{mmol}$ \\
\hline Magnesium & $0.04 \mathrm{mmol}$ & $2.8 \mathrm{mmol}$ \\
\hline Phosphorus & $0.15 \mathrm{mmol}$ & $10.5 \mathrm{mmol}$ \\
\hline
\end{tabular}

"Plus 10-12 per cent for each $1^{\circ} \mathrm{C}$ above normal

Water: Clinical assessment with review of fluid balance charts, haematology and biochemistry are mandatory. Cardiac and renal problems may restrict the load.

Electrolytes: Rough balances of sodium, potassium and chloride can be constructed by measurement of urinary and other losses and monitoring of serum levels. In addition for the maximum utilisation of protein Frost and Smith (1953) recommend the supply of $5 \mathrm{mmol}$ of potassium per gram of amino acid nitrogen infused.

Nitrogen and calories: Lee (1974c) has compiled the estimates shown in Table III from many sources. In addition he has devised a formula for assessing nitrogen balance, based on urinary and blood urea levels (Fig. 3). The nitrogen content of

Table III

Estimates of protein, nitrogen and calorie requirements (after Lee 1974c)

\begin{tabular}{|c|c|c|}
\hline & Uncomplicated postoperative & Hypercatabolic \\
\hline $\mathrm{g} \mathrm{N}_{2} / \mathrm{kg}$ & 0.21 & $0.21-0.29$ \\
\hline $\mathrm{K} \mathrm{cal} / \mathrm{kg}$ & 37 & $46-55$ \\
\hline $\mathrm{K} \mathrm{cal} / \mathrm{gN}_{2}$ & 185 & $185-220$ \\
\hline
\end{tabular}

(A) PROTEIN CATABOLISM = UREA EXCRETION $(\mathrm{g} / 24 \mathrm{~h}) \times 3.5$

(B) BLOOD UREA CORRECTION $=$ BLOOD UREA RISE $(\mathrm{g} / 1) \times \mathrm{B} . \mathrm{W} .(\mathrm{kg}) \times 1.8$

(C) URINARY PROTEIN CORRECTION $=\mathrm{g} / 24 \mathrm{~h}$ then:-

TOTAL PROTEIN CATABOLISM $=(\mathrm{A})+(\mathrm{B})+(\mathrm{C}) \mathrm{g} / 24 \mathrm{~h}$

TOTAL NITROGEN CATABOLISM $=\underline{(\mathrm{A})+(\mathrm{B})+(\mathrm{C}) \mathrm{g} / 24 \mathrm{~h}}$

and:-CALORIE REQUIREMENT

$=$ TOTAL NITROGEN CATABOLISM X $200 \mathrm{~K}$ cals $/ 24 \mathrm{~h}$

Fig. 3. Assessment of nitrogen and energy requirements 
urea is $28 / 60$; nitrogen ' content multiplied by 6.25 gives the protein equivalent; and since creatinine, ammonia and other non-urea nitrogen sources account for approximately $1 / 5$ of urinary nitrogen then:-

Protein catabolism-24 h urine urea in $\mathrm{g} \times 28 / 60 \times 6.25 \times 6 / 5=24 \mathrm{~h}$ urine urea in $\mathrm{g} \mathrm{x} 3.5$.

If the blood urea is rising then the following correction should be added. Assuming urea to be equally distributed throughout the body water, which equals 60 per cent body weight:-

Blood urea correction-Rise in blood urea in $\mathrm{g} / 1 \times 60 \%$, B.W. (kg) $\times 28 / 60$ $\mathrm{x} 6.25=$ Rise in blood urea in $\mathrm{g} / 1 \times 1.8$.

In addition any significant urinary prciein losses should be added in grams per 24 hours.

Minor components. Calcium and phosphorus should be estimated twice weekly (serum and urinary levels) and additions supplied as necessary. In long term Category II patients magnesium, zinc, iron, folate and vitamin $\mathrm{B}_{12}$ estimates should be made every two weeks. Vitamins can be supplied by daily Parentrovite, and weekly vitamin $K$. The addition of one unit of plasma per week to the regime will supply many of the biological trace elements.

\section{Preparations available}

To meet the requirements outlined above three main groups of preparations have been developed :-

a. Amino acid solutions. b. Fat emulsions. c. Carbohydrate solutions.

\section{Amino acid solutions}

The amino acid series, being hydrolysates of the protein casein, contain 1 -amino acids and low molecular peptides. The value of the latter is controversial. The more recently developed Aminoplex and Vamin series are synthetic solutions of 1 -amino acids. The preparations vary in electrolyte composition and the addition of energy substrates. Tweedle (1975) has recently reviewed these solutions.

\section{Fat emulsions}

The Intralipids provide an isotonic high calorie source, with provision of phosphate. However animal studies have caused some concern because of fatty infiltration of many organs. Although this effect is not completely transferred to human studies, there is a general tendency to limit the amount of fat given (usually less than $3 \mathrm{~g}$ per $\mathrm{kg} \mathrm{B} \cdot \mathrm{W}$. per $24 \mathrm{~h}$ ), and the rate of fat infusion.

\section{Carbohydrate solutions}

Glucose is the ideal energy substrate, but hyperosmolarity is a major problem. When solutions greater than 5 per cent concentration are used the urine must be monitored for glycosuria. Renal loss not only fails to utilise the substrate, but adds to fluid balance problems via an osmotic diuresis. Glucose 50 per cent insulin and potassium have been successfully used in hypercatabolic states following severe burns (Hinton et al 1973). This concept is based on the anabolic action of insulin (Fig. 1), but this regime demands constant monitoring of urine 
and blood glucose, and serum potassium. As a result it is not widely used.

Those preparations which are available through the Joint Services Catalogue are listed in Table IV.

\section{Prescribing}

The regime for an individual patient should be prescribed on the basis of the following steps:-

a. Estimate fluids, electrolyte, nitrogen and calorie requirements, with due consideration of any cardiac, renal or hepatic complications. b. Select suitable combinations of the preparations available which meet these requirements, aiming at the following ideal ratios (i) Minimum of $0.2 \mathrm{~g} \mathrm{~N}_{2} / \mathrm{kg}$ B.W. (ii) $\mathrm{K}$ cal: $\mathrm{N}_{2}$ ratio of approximately $200: 1$. (iii) $5 \mathrm{mmol}$ potassium per $\mathrm{g} \mathbf{N}_{2}$. (iv) Minimum of 30 per cent calories supplied as carbohydrates, (c) Reassess the major components daily, others as indicated, and adjust the regime accordingly.

The inclusion of a plain glucose or electrolyte solution in the regime is useful as a "carrier" for drugs and electrolyte additives. Amino acid solutions can be used for this purpose in many cases, but provide an excellent culture medium for any contaminants introduced. Compatibility should always be checked, and nothing other than heparin should be added to Intralipid.

The minimal monitoring requirements of a patient on parenteral nutrition are detailed in Table $\mathrm{V}$.

Table V

Minimum monitoring requirements of a patient during parenteral nutrition

\begin{tabular}{|l|ll|}
\hline ROUTINE & $\begin{array}{l}\text { a. } \\
\text { b, }\end{array}$ & $\begin{array}{l}\text { Four bald hourly chart } \\
\text { carbohydrate infusion }\end{array}$ \\
\hline DAILY & a. & Hb + FBC \\
& b. & Urea + electrolytes \\
& c. & Urinary urea + electrolytes \\
d. & Electrolyte content or abnormal losses \\
\hline TWICE WEEKLY & a. & Serum and urinary calcium and phosphate \\
& b. & LFTs \\
& c. & Blood sugar \\
d. & Body weight \\
\hline FORTNIGHTLY & a. & Iron, Magnesium, folate B:2 and Zinc \\
\hline
\end{tabular}

Examples of the calculation of metabolic requirements in two separate situations are given below.

\section{Example I}

Prolonged ileus following abdominal surgery in a $70 \mathrm{~kg}$ otherwise healthy male. No "adverse factors" in operation.

(i) Patient's weight $=70 \mathrm{~kg}$. (ii) Not hypercatabolic, therefore allow $0.2 \mathrm{~g}$ nitrogen per kg B.W. $=0.2 \times 70=14 \mathrm{~g}$ Nitrogen. (iii) Calorie requirement $=200 \mathrm{~K}$ cal per $\mathrm{g}$ Nitrogen $=14 \times 200=2800 \mathrm{~K} \mathrm{cal}$. (iv) Potassium requirement $=5 \mathrm{~m} / \mathrm{Eq}$ 
Table IV

Solutions for parenteral nutrition available through Joint Services Catalogise

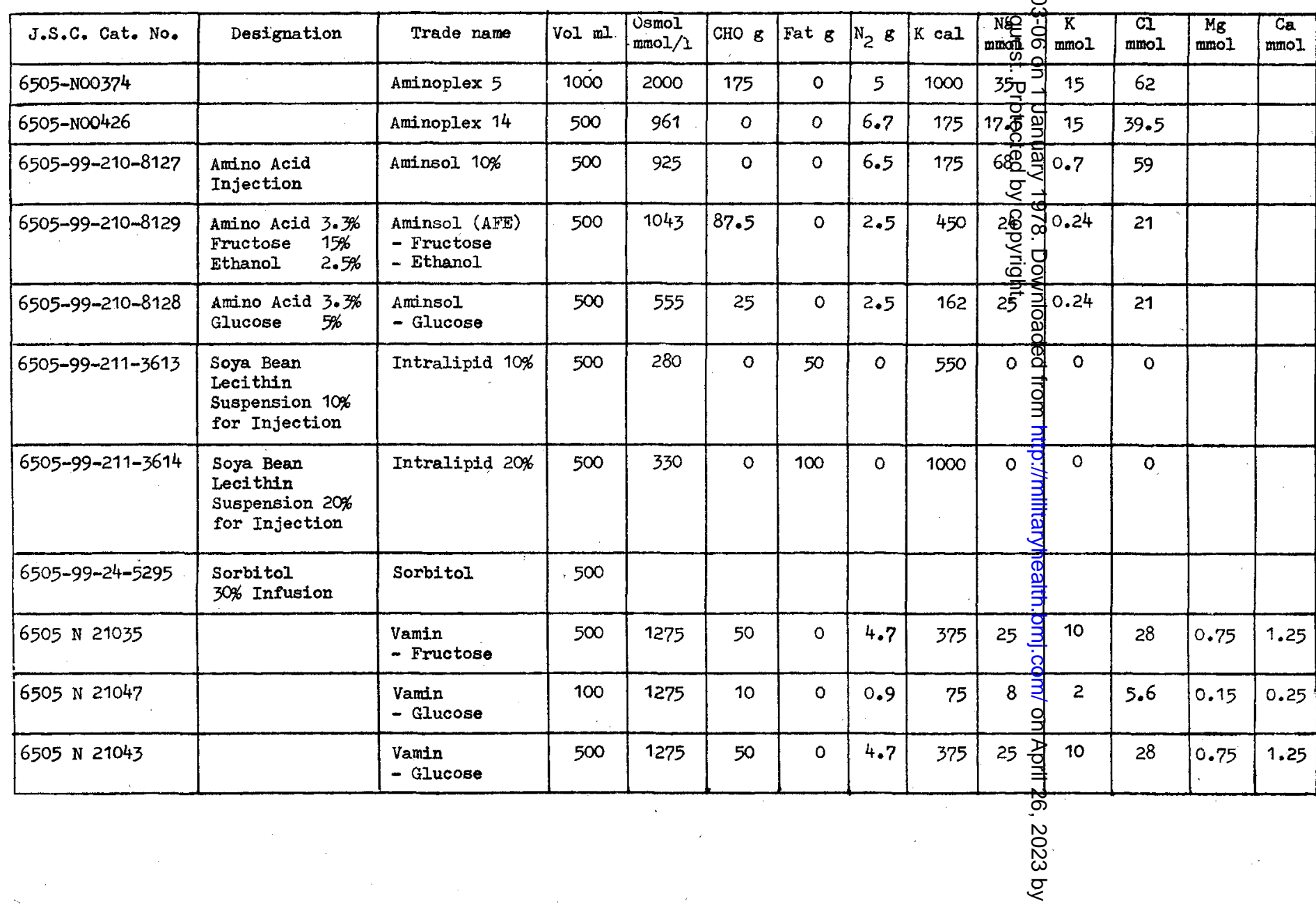


per g Nitrogen $=5 \times 14=90 \mathrm{~m} / \mathrm{Eq}$ Potassium. (v) Fluid requirement $=$ Basal requirement + excess loss $=30 \mathrm{ml}$ per $\mathrm{kg}+$ excess loss $=2100 \mathrm{ml}+$ excess loss $=$ 2500-3000 ml.

Regime "A" in Table VI closely approximates these ideal requirements, and can be given by peripheral lines, avoiding the hazards of a central venous line.

\section{Example II}

A $60 \mathrm{~kg}$ patient with 50 per cent burns, complicated by sepsis. In the preceding 24 hours the urinary urea excretions was $664 \mathrm{mmol}$, and in the same period the blood urea rose by $12 \mathrm{mmol} / 1$.

(i) From urinary urea $664 \mathrm{mmol}=40 \mathrm{~g}$ urea, which represents $40 \times 3.5=$ $140 \mathrm{~g}$ protein catabolized $=140 / 6.25=22.4 \mathrm{~g}$ nitrogen. (ii) Blood urea correction $12 \mathrm{mmol} / \mathrm{l}=720 \mathrm{mg} / \mathrm{l}=0.72 \mathrm{~g} / \mathrm{l}$, which represents $0.72 \times 1.8=1.29 \mathrm{~g}$ protein catabolized $=1.29 / 6.25=0.2 \mathrm{~g}$ nitrogen. (iii) Requirements would therefore be (i) $+($ ii) $=22.6 \mathrm{~g}$ nitrogen. $22.6 \times 200=4520 \mathrm{~K}$ cal. $22.6 \times 5=113 \mathrm{~m} / \mathrm{Eq}$ potassium, to which should be added sodium, chloride and other requirements.

Normally such a patient would be on oral alimentation, possibly with intravenous supplements. However, should the clinical situation so demand, one litre of Aminopex 14 and one litre of Vamin G would supply the amino acid requirements. The additional calorie requirements could be met by the use of Intralipid and 50 per cent Glucose solution, with potassium supplements. Some typical regimes are detailed in Table VI.

\section{Conclusion}

All of us have seen, at some time, a patient in a state of increasing hypercatabolism. We have noted the increasing wasting, sepsis and breakdown of wounds before death. How often was this managed in the words of Peaston (1968) by "Casual instructions to continue with weak sugar and electrolyte solutions, which may provide little or more than a greater volume of extracellular fluid into which the unfortunate subject is invited to dissolve!"

Sugar and electrolyte solutions are no longer the only preparations available. To embark upon a course of parenteral nutrition imposes increased burdens on nursing staff, laboratory staff and clinicians, but to do so successfully contributes a great deal towards reduction of mortality and morbidity.

\section{Acknowledgements}

The authors are grateful to Lieutenant I. Melville, R.A.M.C., D.M.E.D. Ludgershall for his assistance in supplying the details on preparations available through the Joint Services Catalogue. We also thank Mr. O. J. A. Gilmore, M.S., F.R.C.S., F.R.C.S.(Ed.), Consultant Surgeon, St. Bartholomew's Hospital, for his advice during preparation of this paper and Miss J. F. T. Davies and Miss B. J. Smith for secretarial assistance.

\section{REFERENCES}

Allison, S. P. (1974). In Parenteral Nutrition in Acute Metabolic Illness. 1st ed. P. 170. Academic Press. London \& New York. 


\section{Table VI}

Examplea of parenteral nutrition regimes

\begin{tabular}{|c|c|c|c|c|c|c|c|c|c|c|c|c|c|}
\hline \multicolumn{5}{|c|}{$\begin{array}{c}\text { Constituents of regime } \\
\text { in bottles }\end{array}$} & \multirow[t]{2}{*}{ Regime } & \multirow[t]{2}{*}{ Vol ml } & \multirow[t]{2}{*}{$\mathrm{CHO}_{\mathrm{B}}$} & \multirow[t]{2}{*}{ Fat $\mathrm{g}$} & \multirow{2}{*}{$\mathrm{N}_{2} \mathrm{~B}$} & \multirow{2}{*}{\multicolumn{2}{|c|}{ K $\operatorname{cal} \stackrel{e}{\stackrel{c}{\infty}} \oint_{\mathrm{Na}} \mathrm{mmol}$}} & \multirow[t]{2}{*}{ K mmol } & \multirow[t]{2}{*}{ C1 mol } \\
\hline$E$ & $\mathrm{D}$ & $\mathrm{C}$ & $B$ & A & & & & & & & & & \\
\hline 1 & & & & & Aminoplex 5 & 1000 & 175 & 0 & 5 & 1000 융 & 35 & 15 & 62 \\
\hline \multirow[t]{2}{*}{1} & & & 1 & & Aminoplex 14 & 500 & 0 & 0 & 6.7 & 175 远事 & 17.5 & 15 & 39.5 \\
\hline & $2^{* *}$ & $2^{* *}$ & & $2^{* *}$ & Aminosol Fructose Ethanol & 500 & 87.5 & 0 & 2.5 & $450 \stackrel{\sigma}{\frac{\sigma}{4}}$ & 24 & 0.24 & 21 \\
\hline \multirow[t]{2}{*}{1} & 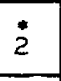 & $\dot{2}$ & 1 & $2^{* *}$ & Vamin GIucose & 500 & 50 & 0 & 4.7 & 325 흥 & 25 & 10 & 28 \\
\hline & & 1 & & 1 & Intralipid $10 \%$ & 500 & 0 & 50 & 0 & $550 \stackrel{+}{9}$ & 0 & 0 & 0 \\
\hline 1 & & & 1 & & Intralipid $20 \%$ & 500 & 0 & 100 & 0 & $1000 \$$ & 0 & 0 & 0 \\
\hline \multirow[t]{4}{*}{$i$} & & & & . & Dextrose $50 \%$ & 500. & 250 & 0 & 0 & 1000 & 0 & 0 & 0 \\
\hline & 1 & & $2^{* *}$ & & Dextrose $20 \%$ & 500 & 100 & 0 & 0 & 400 . 专 & 0 & 0 & 0 \\
\hline & i & & & * & Dextrose $5 \%$ & 500 & 25 & 0 & 0 & 100 & 0 & 0 & 0 \\
\hline & & 1 & & & Hartmann's solution & 500 & 0 & 0 & 0 & 0 & 65 & 2.7 & 56 \\
\hline \multirow[t]{6}{*}{3} & 4 & 3 & 3 & 5 & Potassium Chloride $1 \mathrm{~g}^{*}$ & - & - & - & - & - & - & .13 .5 & 13.5 \\
\hline & & & & & Standard & 3000 & 300 & 50 & 14.4 & 2300 & 98 & 88.0 & 165.5 \\
\hline & & & & & Low Sodium & 2500 & 250 & 100 & 11.4 & $2300 \quad 8$ & 42.5 & 65.5 & 108 \\
\hline & & & & & High Sodium & 3000 & 275 & 50 & 14.4 & 2300 & 163 & 63.7 & 194.5 \\
\hline & & & 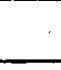 & & Fat Free & 3000 & 400 & 0 & 14.4 & $2050 \quad \frac{I}{9}$ & 98 & 74.5 & 154 \\
\hline & & & & & High Cal/High Protein E & 3000 & 475 & 100 & 16.4 & 3500 d & 77.5 & 80.5 & 140.5 \\
\hline
\end{tabular}

* = Addition of 1 g Potassium Chloride. Plus daily Parentrovite + weekly Vitamin $\mathrm{K}$ 
Burri, G. and HenkemeYer, H. (1972). In Parenteral Nutrition. 1st ed. P. 234. Churchill Livingstone. Edinburgh \& London.

Frost, P. M. and SMith, J. L. (1953). Metabolism 2, 529.

HADFIELD, J. (1975). Ann. roy. Coll. Surg. Engl. 53, 45.

Heatley, R. C. and Hughes, L. E. (1974). In Proceedings of the International Conference on Parenteral Nutrition. Montpellier, France.

Hinton, P., Allison, S. P., LitTlejohn, S. and Lloyd, J. (1973). Lancet ii, 218.

Ilexs, A. (1948). J. Amer. med. Ass. $138,500$.

KinneY, J. N., Duke, J. M., Long, C. L. and Gump, F. S. (1970). J. clin. Path. 23, Suppl. 4, 65 .

Law, D. K., Dudrick, S. J. and Abdou, N. I. (1973). Ann. intern. Med. 79, 545.

LEE, H A. (1974a). In Parenteral Nutrition in Acute Metabolic Illness. 1st ed. P. VII. Academic Press. London \& New York.

LEE, H. A. (1974b). Brit. J. Hosp. Med. 11.

LEE, H. A. (1974c). In Parenteral Nutrition in Acute Metabolic Illness. 1st ed. P. 314. Academic Press. London \& New York.

Moore, F. D. (1959). In Metabolic Care of the Surgical Patient. Saunders. Philadelphia.

Peaston, M. J. T. (1968). Hosp. Med. 2, 708.

TWEEDLE, D. (1975). Brit. J. Hospital Med. $13,81$.

Wretlind, A. (1974). In Parenteral Nutrition in Acute Metabolic Illness. 1st ed. P. 364. Academic Press. London \& New York.

\title{
ELECTRO-ENCEPHALOGRAPHY AND EVEREST CLIMBERS
}

\author{
LIEUTENANT-COLONEL P. ABRAHAM \\ M.R.C.Psych, D.T.M.\&H., R.A.M.C.
}

J. roy. Army med. Cps. 1978. 124, 84-87

Author's note: I had not appreciated from the limited translation kindly made available to me by Dr Charles F. Clark of Colorado that Dr Ryn made E.E.G. recordings before as well as after an expedition. As a result the following amendments are made to the above quoted paper:-

Page 84. Introduction, paragraph 2, line 1-Delete "This was also the first" and insert "It was also only the second". Line 2-After "off". add "The first report (Ryn 1970) described pathological tracings in 11 out of 30 climbers following an expedition". Line 3-for "the climbers" read "our climbers".

Page 86. Discussion, paragraph 3, line 5-After "seizures" add "(Scott 1978)".

Page 87. References-After "Prior etc" add "SCOTT, D. F. (1978). Photoconvulsive responses in patients over 30 years of age. Electroencep't. clin. Neurophysiol. (In press)". After "Ward etc" add--"Ryn, Z. (1970). Zaburzenia Psychiczne U Alpinistow W Warunkach Stresu Wysokogorskiego. Krakow". 